\title{
Nutrition in Team Sports
}

\author{
Iñigo Mujika ${ }^{a, b}$ Louise M. Burke \\ a USP Araba Sport Clinic, Vitoria-Gasteiz, and ${ }^{b}$ Department of Physiology, Faculty of Medicine and \\ Odontology, University of the Basque Country, Leioa, Spain; ' $S p o r t s$ Nutrition, Australian Institute of Sport, \\ Canberra, A.C.T., Australia
}

\section{Key Words}

Team sports · Football • Physiology • Fatigue $\cdot$ Glycogen • Carbohydrate $\cdot$ Fluid

\begin{abstract}
Team sports are based on intermittent high-intensity activity patterns, but the exact characteristics vary between and within codes, and from one game to the next. Despite the challenge of predicting exact game demands, performance in team sports is often dependent on nutritional factors. Chronic issues include achieving ideal levels of muscle mass and body fat, and supporting the nutrient needs of the training program. Acute issues, both for training and in games, include strategies that allow the player to be well fuelled and hydrated over the duration of exercise. Each player should develop a plan of consuming fluid and carbohydrate according to the needs of their activity patterns, within the breaks that are provided in their sport. In seasonal fixtures, competition varies from a weekly game in some codes to 2-3 games over a weekend road trip in others, and a tournament fixture usually involves 1-3 days between matches. Recovery between events is a major priority, involving rehydration, refuelling and repair/adaptation activities. Some sports supplements may be of value to the
\end{abstract}

team athlete. Sports drinks, gels and liquid meals may be valuable in allowing nutritional goals to be met, while caffeine, creatine and buffering agents may directly enhance performance.

Copyright $\odot 2011$ S. Karger AG, Basel

\section{Introduction}

Team sports share the common feature of intermittent high-intensity activity patterns, but experience marked variability of game characteristics between sports, between positions and playing styles within the same sport, and from one match to the next. This creates a diversity of physiological challenges and nutritional needs for team sport athletes. The goal of this paper is to overview 4 key areas in which nutrition can optimize performance in team sports: achievement of ideal body composition, the philosophy of nutritional support for training, strategies for meeting fluid and fuel needs during competition, and supplements and ergogenic aids with benefits to team sports.

\section{KARGER \\ Fax +4161306 1234 \\ E-Mail karger@karger.ch}

www.karger.com
(C) 2011 S. Karger AG, Basel

$0250-6807 / 10 / 0576-0026 \$ 26.00 / 0$

Accessible online at:

www.karger.com/anm
Iñigo Mujika, $\mathrm{PhD}$

USP Araba Sport Clinic

Paseo de la Biosfera s/n

ES-01013 Vitoria-Gasteiz (Spain)

Tel. +3494503 0400, Fax +3494503 0401, E-Mail inigo.mujika@ usphospitales.com 


\section{Physiological Characteristics of Match Play in Team Sports}

Most team sports (e.g. basketball, football, hockey, rugby, volleyball) can be described as moderate- to longduration exercise including repeated bouts of high-intensity activity interspersed with periods of low-to-moderate active recovery or passive rest. From a physiological perspective, team sports are characterized by the moderateto-long distances covered by the players during match play (e.g. 8-12 km in association football), but also the variable activity pattern (e.g. in excess of 800 activity changes per football match, including walking, jogging, cruising, sprinting, backing, jumping, tackling and heading $[1,2])$.

Players' ability to perform repeated sprints with shortduration recovery in between is an important determinant of performance in intermittent team sports $[3,4]$. This activity pattern determines to a great extent the physiological requirements of team sports. As shown by physiological measurements conducted during match play, these requirements include not only a high aerobic capacity, but also a high glycolytic capacity and a welldeveloped phosphocreatine breakdown/resynthesis system [5-10]. Various factors may be involved in the cause of fatigue or suboptimal performance in this context, with factors related to nutrition being summarized in table 1 .

\section{Achieving Ideal Physique for Team Sports}

Although the physique requirements of team sports vary across and within sports, there are some common elements. Players who are involved in a fast and agile game, covering significant distances during a match, are generally aided by a lighter and lean physique. Normally, the body fat levels of team sport players do not reach the low levels typical of endurance athletes such as runners and cyclists. However, observations among professional team sports have noted a reduction in body fat levels across players in general $[11,12]$ and new levels of leanness among 'midfield' players (table 2). The requirement to wear Lycra bodysuit uniforms in some women's team competitions has also contributed to an increased interest in loss of body fat among team players, although in this case it may be driven by aesthetic interests as much as by performance goals.

Many players follow the nutritional strategies of strength-training athletes emphasizing protein intake and using purported muscle gain supplements. Recent research using tracer techniques has focused on the best feeding strategies following a bout of resistance exercise. Various investigations have found that the maximal protein synthetic response is produced when resistance exercise is followed by the intake of protein that is high quality in terms of its content of essential amino acids and rapidly digested [13; West et al., unpublished data]. Despite the belief that large amounts of protein are needed for gains from resistance exercise, a dose-response study has found that the maximal synthetic response to a training bout was achieved with the intake of 20-25 $\mathrm{g}$ of highquality protein [14]. Indeed, intakes higher than this were associated with greater protein oxidation.

\section{Fuel for Training Adaptation, Recovery and Match Preparation}

According to table 1, a mismatch between the carbohydrate needs of training and competition and dietary intake can be a cause of poor performance in team sports. There are few studies of the fuel demands of team sport players during training or competition, with the available evidence being focused on the match play of soccer players. Significant muscle glycogen depletion has been shown to occur over the course of a football match $[6,15$, 16], with reduced fuel stores being associated with a reduction in the distance covered and/or running speed during the second half of a match $[6,15]$. The current guidelines for carbohydrate intakes amended to suit a range of needs for team players are summarized in table 3 , with the rationale for these recommendations now being discussed.

There are several studies from both field and laboratory viewpoints which have examined the value of fuelling up in preparation for team sport. In one investigation, professional soccer players completed an intermittent high-intensity protocol of field and treadmill running lasting approximately $90 \mathrm{~min}$, after a 48 -hour intake of high-carbohydrate (approx. $8 \mathrm{~g} / \mathrm{kg} /$ day) or moderate-carbohydrate (approx. $4.5 \mathrm{~g} / \mathrm{kg} /$ day) diets [17]. The high-carbohydrate diet increased intermittent running to fatigue at the end of the protocol by approximately $1 \mathrm{~km}(\mathrm{p}<$ 0.05 ), although the performance enhancement was more marked in some participants than others [17]. Similarly, movement analysis of a 4-a-side indoor soccer game lasting $90 \mathrm{~min}$ was undertaken following $48 \mathrm{~h}$ of high (approx. $8 \mathrm{~g} / \mathrm{kg} /$ day) or moderate (approx. $3 \mathrm{~g} / \mathrm{kg} /$ day) carbohydrate intake [18]. The high-carbohydrate diet in- 
Table 1. Factors related to nutrition that could produce fatigue or suboptimal performance in team sports

\begin{tabular}{|c|c|c|}
\hline Factor & Description & $\begin{array}{l}\text { Examples of high-risk/common } \\
\text { occurrence in team sports }\end{array}$ \\
\hline Dehydration & $\begin{array}{l}\text { Failure to drink enough fluid to replace } \\
\text { sweat losses during a game. May be } \\
\text { exacerbated if player begins match in } \\
\text { fluid deficit }\end{array}$ & $\begin{array}{l}\text { Matches played in hot conditions, } \\
\text { particularly for players with high } \\
\text { activity patterns and/or heavy } \\
\text { protective garments. Repeated } \\
\text { matches (e.g. tournaments) may } \\
\text { increase risk of compounding } \\
\text { dehydration from one match to the } \\
\text { next }\end{array}$ \\
\hline $\begin{array}{l}\text { Muscle glycogen } \\
\text { depletion }\end{array}$ & $\begin{array}{l}\text { Depletion of important muscle fuel due } \\
\text { to high utilization in a single match } \\
\text { and/or poor recovery of stores from } \\
\text { previous activity/match }\end{array}$ & $\begin{array}{l}\text { 'Running' players with large total } \\
\text { distances covered at high intensities } \\
\text { (e.g. midfield players in soccer, } \\
\text { Australian rules football). Repeated } \\
\text { matches (e.g. tournament) may } \\
\text { increase risk of poor refueling from } \\
\text { one match to the next }\end{array}$ \\
\hline $\begin{array}{l}\text { Hypoglycemia and } \\
\text { depletion of central } \\
\text { nervous system fuels } \\
\text { (brain glycogen) }\end{array}$ & $\begin{array}{l}\text { Reduction in blood glucose } \\
\text { concentrations due to poor } \\
\text { carbohydrate availability }\end{array}$ & $\begin{array}{l}\text { May occur in players with high } \\
\text { carbohydrate requirements (see } \\
\text { above) who fail to consume } \\
\text { carbohydrate during the match }\end{array}$ \\
\hline $\begin{array}{l}\text { Disturbance of muscle } \\
\text { acid-base balance }\end{array}$ & $\begin{array}{l}\text { High rates of } \mathrm{H}+\text { production via } \\
\text { anaerobic glycolytic power system }\end{array}$ & $\begin{array}{l}\text { Prolonged or repeated intervals of } \\
\text { high-intensity activities }\end{array}$ \\
\hline $\begin{array}{l}\text { Depletion of } \\
\text { phosphocreatine stores }\end{array}$ & $\begin{array}{l}\text { Inadequate recovery of } \\
\text { phosphocreatine system of power } \\
\text { production }\end{array}$ & $\begin{array}{l}\text { Prolonged or repeated intervals of } \\
\text { high-intensity activities }\end{array}$ \\
\hline $\begin{array}{l}\text { Gastrointestinal } \\
\text { disturbances }\end{array}$ & $\begin{array}{l}\text { Gastrointestinal disturbances, } \\
\text { including vomiting and diarrhea may } \\
\text { directly reduce performance as well as } \\
\text { interfere with nutritional strategies } \\
\text { aimed at managing fluid and fuel status }\end{array}$ & $\begin{array}{l}\text { Poorly chosen intake of food and fluid } \\
\text { before and/or during match }\end{array}$ \\
\hline Salt depletion (?) & $\begin{array}{l}\text { Inadequate replacement of sodium lost } \\
\text { in sweat. There is anecdotal evidence } \\
\text { that salt depletion may increase the risk } \\
\text { of a specific type of whole body muscle } \\
\text { cramp }\end{array}$ & $\begin{array}{l}\text { Salty sweaters - individuals with high } \\
\text { sweat rates and high sweat sodium } \\
\text { concentrations who may acutely or } \\
\text { chronically deplete exchangeable } \\
\text { sodium pools }\end{array}$ \\
\hline $\begin{array}{l}\text { Water intoxication/ } \\
\text { hyponatremia (low } \\
\text { blood sodium) }\end{array}$ & $\begin{array}{l}\text { Excessive intake of fluids can lead to } \\
\text { hyponatremia ranging from mild } \\
\text { (often asymptomatic) to severe (can } \\
\text { be fatal) }\end{array}$ & $\begin{array}{l}\text { Players with low sweat losses (e.g. } \\
\text { low activity or game time) who } \\
\text { overzealously consume fluid before } \\
\text { and during a match }\end{array}$ \\
\hline
\end{tabular}

creased muscle glycogen by $38 \%$ and allowed soccer players to complete approximately $33 \%$ more high-intensity work during the game.

Abt et al. [19] examined the effect of a high-carbohydrate diet on the performance of dribbling and shooting skills of football players using a simulated game protocol. The findings of this study indicated that the high-carbo- hydrate diet did not increase the ability of players to shoot or dribble. Several explanations are possible: either muscle glycogen depletion may not impair the ability of the player to execute game skills; alternative fatigue mechanisms such as dehydration or increased lactate production may be causative factors in the reduction in skill performance, or the treadmill protocol employed failed to 
Table 2. Risk factors and strategies to manage unwanted gain of body fat among players in team sports (adapted from Burke [24])

\begin{tabular}{ll}
\hline Risk factor & Strategies to address risk factor \\
\hline $\begin{array}{l}\text { Substantial reduction in } \\
\text { activity levels during the } \\
\text { off-season or injury }\end{array}$ & $\begin{array}{l}\text { Encouragement of self-monitored } \\
\text { off-season activity program or suitable } \\
\text { cross-training and rehabilitation program } \\
\text { during injury }\end{array}$ \\
\hline $\begin{array}{l}\text { Poor eating and drinking } \\
\text { practices during the off- } \\
\text { season or injury, including } \\
\text { 'boredom eating' and }\end{array}$ & $\begin{array}{l}\text { Development of individualized off-season } \\
\text { dietary plan, allowing greater food } \\
\text { 'binge' practices with } \\
\text { eating and alcohol intake }\end{array}$ \\
$\begin{array}{l}\text { intake to match reduced energy expenditure } \\
\text { Counselling regarding food and alcohol } \\
\text { binges to allow a more moderate approach } \\
\text { to social eating occasions }\end{array}$ \\
\hline
\end{tabular}

Poor nutrition knowledge and practical skills leading to poor food choices and reliance on takeaway foods

Nutrition education activities to improve nutrition awareness and identify nutrientdense, less energy-dense foods Individual counselling and development of dietary plan

Practical nutrition activities (e.g. supermarket tours, cooking classes) to teach domestic skills and knowledge of sound choices in restaurants and takeaway outlets

Chaotic meal patterns and displaced meals leading to poor awareness of actual food intake in a day

Counselling in time management and domestic skills to develop a sound eating routine

Where problem commonly occurs among players and is exacerbated by team commitments, provision of meals and snacks within team environment

Development of nutrition education
Residential situation (e.g. college, foster family) exposing athlete to inappropriate food choices resources or activities for caterers regarding special nutritional needs of athletes Player education to make sound choices from available options or request modifications to menu Identification of food items that can be added to, or substituted in, present meals to improve overall menu

Constant travel leading to disturbance of home routine; game schedule of frequent matches where emphasis is on fuelling and recovery

Regular excessive intake of alcohol, often in conjunction with inappropriate eating
Development of an individualized eating plan that provides adequate opportunities to meet player's fuel needs for match preparation and recovery, without exceeding appropriate energy budget

Development of nutrition education resources providing objective information about excessive intake of alcohol and sports performance, including body fat management Individual counselling to negotiate contract regarding appropriate alcohol intake practices induce a degree of glycogen depletion or fatigue large enough to cause a significant fall in skill performance [19].

Finally, players from 2 elite Swedish ice hockey teams were randomly allocated to either a carbohydrate-enriched $(8.4 \mathrm{~g} / \mathrm{kg} /$ day $)$ or mixed $(6.2 \mathrm{~g} / \mathrm{kg} /$ day $)$ diet in the recovery period between 2 games held $72 \mathrm{~h}$ apart. Muscle glycogen concentrations were reduced after the first game for all players, but restoration levels were $45 \%$ higher in the carbohydrate-loaded players before the next game. Distance skated, number of shifts skated, amount of time skated within shifts, and skating speed were all increased in the carbohydrate-loaded players compared with the mixed diet group, with the differences being most marked in the third period [20].

Rapid refuelling after the completion of the game will be important in situations where there is only a short interval between matches or where the player needs to undertake a significant training load between matches (table 3). There are few studies of actual glycogen restoration following real or simulated competition in team sport; these are limited to soccer and show divergent results with both success [21] and failure [22] to replenish glycogen stores within $24 \mathrm{~h}$. Potential reasons for failure to refuel effectively after competition include interference with glycogen storage due to the presence of muscle damage arising from eccentric activities [23] or contact injuries, and excessive intake of alcohol [24]. Current sports nutrition guidelines for everyday eating recommend that athletes consume adequate carbohydrate to meet the fuel requirements of their training program, thus allowing training sessions to be undertaken with high carbohydrate availability (for a review, see Burke [25]).

However, some studies have found that when exercise is undertaken with low muscle glycogen content, the transcription of a number of genes involved in training adaptations is enhanced (for a review, see Baar and McGee [26]). This information explains the recently described 'train low, compete high' paradigm: training with low glycogen/carbohydrate availability to enhance the training response, but competing with high fuel availability to promote performance. There are a number of potential ways to reduce carbohydrate availability for the training environment, including doing 2 training sessions in close succession without opportunity for refuelling $[27,28]$, or training in a fasted state with only water intake [29]. As reviewed by Burke [25], it should be pointed out that these do not always promote a lowcarbohydrate diet per se nor restrict carbohydrate availability for all training sessions, and some studies have 
Table 3. Fuel requirements for training and match play adapted for team players (adapted from Burke and Cox [39])

Situation
Carbohydrate targets per kg of the player's body weight

\begin{tabular}{|c|c|c|}
\hline \multicolumn{3}{|c|}{ Daily needs for fuel and recovery ${ }^{1}$} \\
\hline Minimal & $\begin{array}{l}\text { Light training program (low intensity or skill-based } \\
\text { exercise) }\end{array}$ & $3-5$ g per kg each day \\
\hline Moderate & $\begin{array}{l}\text { Moderate exercise program (i.e. approx. } 1 \text { h per } \\
\text { day) }\end{array}$ & 5-7 g per kg each day \\
\hline High & $\begin{array}{l}\text { Endurance program (i.e., } 1-3 \mathrm{~h} \text { per day of } \\
\text { moderate- to high-intensity exercise) }\end{array}$ & $6-10 \mathrm{~g}$ per kg each day \\
\hline Very high & $\begin{array}{l}\text { Extreme exercise (i.e., }>4-5 \text { h per day of moderate- } \\
\text { to high-intensity exercise) }\end{array}$ & 10-12 g per kg each day \\
\hline \multicolumn{3}{|c|}{ Special situations requiring fuel } \\
\hline $\begin{array}{l}\text { Maximal daily } \\
\text { refuelling }\end{array}$ & $\begin{array}{l}\text { Postevent recovery or aggressive fuelling } \\
\text { ('carbohydrate loading') before the game }\end{array}$ & $7-12 \mathrm{~g}$ per $\mathrm{kg}$ for each $24 \mathrm{~h}$ \\
\hline \multirow[t]{2}{*}{$\begin{array}{l}\text { Speedy } \\
\text { refuelling }\end{array}$} & $\begin{array}{l}\text { Less than } 8 \mathrm{~h} \text { recovery between } 2 \text { demanding } \\
\text { workouts }\end{array}$ & $\begin{array}{l}1-1.2 \mathrm{~g} \text { per } \mathrm{kg} \text { immediately after first } \\
\text { session }\end{array}$ \\
\hline & & $\begin{array}{l}\text { Repeated each hour until the normal } \\
\text { meal schedule is resumed }\end{array}$ \\
\hline $\begin{array}{l}\text { Pre-game } \\
\text { fuelling }\end{array}$ & Before the game & 1-4 g per kg eaten $1-4 \mathrm{~h}$ before exercise \\
\hline \multirow[t]{3}{*}{ During game } & Short games or small fuel demands & $\begin{array}{l}\text { Small amounts of carbohydrate - } \\
\text { including simply tasting carbohydrate }\end{array}$ \\
\hline & Moderate game demands (e.g. games 60-90 min) & $30-60 \mathrm{~g} / \mathrm{h}$ \\
\hline & $\begin{array}{l}\text { Large game fuel demands (e.g. games }>2 \mathrm{~h} \text { for } \\
\text { mobile players). May also include players who start } \\
\text { match poorly fuelled }\end{array}$ & Perhaps up to $80-90 \mathrm{~g} / \mathrm{h}$ \\
\hline
\end{tabular}

\footnotetext{
${ }^{1}$ Note that players with a high body mass or players undertaking a weight loss program may be better suited to reduce their fuel intake to the needs of the previous category.
}

reported a reduction in self-chosen training intensity $[28,30]$.

One study has applied the 'train low' theory to a team sport model. Morton et al. [31] followed the progress of 3 groups of recreationally active men who undertook 4 weekly sessions of a set program of high-intensity running with either high carbohydrate availability (1 session per day), train low (twice-a-week training with 2 training sessions in succession), or train low + glucose (as before, but with glucose intake before and during the second session). All groups recorded a similar improvement in $\mathrm{VO}_{2} \max$ (approx. 10\%) and distance run during a Yo-Yo Intermittent Recovery Test 2 protocol (approx. 18\%), although the group who trained with low availability of exogenous and endogenous carbohydrate sources showed greater metabolic advantages such as increased activity of oxidative enzymes. Clearly, more work is needed on this interesting topic.

\section{Fuel and Fluid for Match Play}

Table 1 summarizes a number of nutritional factors that could be associated with fatigue during a team game. These include inadequate fuel and fluid status; factors that can be addressed by the intake of appropriate drinks and sports products during a match. Given the intermittent nature of team sports, they often offer frequent opportunities to ingest fluid and energy during breaks between periods, time-outs, substitutions or breaks in play [24]. Drinking opportunities for selected team sports are summarized in table 4.

Dehydration is directly related to reduced exercise capacity, increased perception of effort, and deterioration of mental performance and football skill performance (for a review, see Burke and Hawley [32]). Various studies have shown that elite football players do not drink a sufficient amount to replace their sweat loss during training $[33,34]$. 
Table 4. Opportunities to drink during a match play in selected team sports (adapted from Burke and Hawley [32])

\begin{tabular}{|c|c|c|c|}
\hline Sport & $\begin{array}{l}\text { Intervals } \\
\text { of play }\end{array}$ & $\begin{array}{l}\text { Opportunities } \\
\text { to drink }\end{array}$ & Comments \\
\hline $\begin{array}{l}\text { Basket- } \\
\text { ball }\end{array}$ & $\begin{array}{l}4 \times 10-12 \mathrm{~min} \\
+ \text { substantial } \\
\text { time-on, } \\
\text { unlimited } \\
\text { substitutions, } \\
\text { time-outs }\end{array}$ & $\begin{array}{l}\text { Quarter-time } \\
\text { breaks, } \\
\text { time-outs, } \\
\text { substitutions }\end{array}$ & $\begin{array}{l}\text { Fluids must be } \\
\text { consumed on } \\
\text { court sidelines }\end{array}$ \\
\hline $\begin{array}{l}\text { Field } \\
\text { hockey }\end{array}$ & $\begin{array}{l}2 \times 35 \mathrm{~min} \\
\text { unlimited } \\
\text { substitutions }\end{array}$ & $\begin{array}{l}\text { Half-time, } \\
\text { substitutions, } \\
\text { pauses in play }\end{array}$ & $\begin{array}{l}\text { Fluids must be } \\
\text { consumed at } \\
\text { sidelines; } \\
\text { players must } \\
\text { not leave field }\end{array}$ \\
\hline $\begin{array}{l}\text { Ice } \\
\text { hockey }\end{array}$ & $\begin{array}{l}3 \times 20 \mathrm{~min}+ \\
\text { substantial } \\
\text { time-on, } \\
\text { unlimited } \\
\text { substitutions, } \\
\text { time-outs }\end{array}$ & $\begin{array}{l}\text { Third-time } \\
\text { breaks, } \\
\text { time-outs, } \\
\text { substitutions, } \\
\text { pauses in play }\end{array}$ & $\begin{array}{l}\text { Players must } \\
\text { drink at bench }\end{array}$ \\
\hline Rugby & $\begin{array}{l}2 \times 40 \mathrm{~min}, \\
\text { limited } \\
\text { substitutions }\end{array}$ & $\begin{array}{l}\text { Half-time break, } \\
\text { substitutions, } \\
\text { pauses in play }\end{array}$ & $\begin{array}{l}\text { Trainers may } \\
\text { run onto field } \\
\text { with fluid } \\
\text { bottles during } \\
\text { pauses in play }\end{array}$ \\
\hline $\begin{array}{l}\text { Foot- } \\
\text { ball }\end{array}$ & $\begin{array}{l}2 \times 45 \mathrm{~min} \text {, } \\
\text { substitutions } \\
\text { without } \\
\text { replacement }\end{array}$ & $\begin{array}{l}\text { Half-time break, } \\
\text { pauses in play } \\
\text { (drink must be } \\
\text { taken at sideline) }\end{array}$ & $\begin{array}{l}\text { Fluids must be } \\
\text { consumed at } \\
\text { sidelines; } \\
\text { players must } \\
\text { not leave field }\end{array}$ \\
\hline $\begin{array}{l}\text { Volley- } \\
\text { ball }\end{array}$ & $\begin{array}{l}\text { First to } 3 \text { sets, } \\
\text { limited } \\
\text { substitutions, } \\
\text { time-outs }\end{array}$ & $\begin{array}{l}\text { Time-outs, } \\
\text { substitutions, } \\
\text { breaks between } \\
\text { sets }\end{array}$ & $\begin{array}{l}\text { Fluids must be } \\
\text { consumed at } \\
\text { sidelines }\end{array}$ \\
\hline
\end{tabular}

Maughan et al. [35] measured fluid balance and sweat electrolyte losses during a competitive football match played at an ambient temperature of $6-8{ }^{\circ} \mathrm{C}$ (relative humidity $50-60 \%)$. Study results showed a large individual variability in hydration status, sweat losses, and drinking behaviors in this cool environment, highlighting the need for individualized assessment of hydration status to optimize fluid replacement strategies. In a recent investigation, Mohr et al. [36] indicated that net fluid loss during a football game in the heat was $>2 \%$ of body mass, and correlations were observed between net fluid loss and repeated sprint test fatigue index after the game $(\mathrm{r}=0.73)$.

$\mathrm{McGregor}$ et al. [37] examined the effect of intermittent high-intensity shuttle running and fluid ingestion on the performance of a football skill in semi-professional players. Performance of the skill test after a trial with no fluid deteriorated by $5 \%$, but was maintained during the fluid ingestion trial. In addition, mean heart rate, perceived exertion, serum aldosterone, osmolality, sodium and cortisol responses during the test were higher when no fluid was ingested. Nevertheless, Edwards and Noakes [38] suggest that dehydration is only an outcome of complex physiological control (operating a pacing plan) and no single metabolic factor is causal of fatigue in elite soccer. Other hydration and nutritional factors that could produce fatigue in football include hypoglycemia, other mechanisms of 'central fatigue' involving neurotransmitters, hyponatremia, and gastrointestinal discomfort and upset [39].

Nicholas et al. [40] examined the effects of ingesting a $6.9 \%$ carbohydrate-electrolyte solution on endurance capacity during a prolonged intermittent, high-intensity shuttle running test. The solution was ingested immediately prior to exercise $(5 \mathrm{ml} / \mathrm{kg})$ and every $15 \mathrm{~min}$ thereafter $(2 \mathrm{ml} / \mathrm{kg})$. The subjects were able to continue running longer when fed the carbohydrate-electrolyte solution. More recently, Ali et al. [41] investigated the effect of ingesting a similar carbohydrate-electrolyte solution in subjects with reduced carbohydrate stores, during an intermittent shuttle running test, and football passing and shooting performance. The carbohydrate-electrolyte solution enabled subjects with compromised glycogen stores to better maintain skill and sprint performance than when ingesting fluid alone.

In addition to the physiological and metabolic benefits, Backhouse et al. [42] studied the effects of carbohydrate ingestion during prolonged high-intensity intermittent exercise on affect and perceived exertion. Their results showed that perceived activation was lower without carbohydrate ingestion during the last $30 \mathrm{~min}$ of exercise, and this was accompanied by lowered plasma glucose concentrations. In the carbohydrate trial, rating of perceived exertion was maintained in the last $30 \mathrm{~min}$ of exercise but carried on increasing in the placebo trial. These authors concluded that carbohydrate ingestion during prolonged high-intensity exercise elicits an enhanced perceived activation profile that may impact upon task persistence and performance.

Clarke et al. [43] investigated the effect of the provision of sports drink during football-specific exercise. On 2 occasions, $7 \mathrm{ml} / \mathrm{kg}$ carbohydrate-electrolyte or placebo solutions were ingested at 0 and $45 \mathrm{~min}$. On a third trial, the same volume of carbohydrate-electrolyte was consumed in smaller volumes at $0,15,30,45,60$, and $75 \mathrm{~min}$. This manipulation of the timing and volume of ingestion elic- 
Table 5. Sports foods and supplements that are of likely benefit to team sport players (adapted from Burke [24])

\begin{tabular}{ll}
\hline Product & Comment \\
\hline $\begin{array}{l}\text { Use in achieving documented nutrition goals } \\
\text { Sport drinks }\end{array}$ & $\begin{array}{l}\text { Use to refuel and rehydrate during prolonged training sessions and matches and to rehydrate after the session. } \\
\text { Contains some electrolytes to help replace sweat losses and increase voluntary intake of fluid }\end{array}$ \\
\hline Sport gels & $\begin{array}{l}\text { Convenient and compact carbohydrate source that can be used for additional refuelling during matches and } \\
\text { prolonged training sessions, especially if water is used for hydration goals }\end{array}$ \\
\hline Sport bars & $\begin{array}{l}\text { Convenient, portable, and easy-to-consume source of carbohydrate, protein, and micronutrients for prematch } \\
\text { meal or postexercise recovery }\end{array}$ \\
& $\begin{array}{l}\text { Low-bulk and portable form of energy and nutrients that can contribute to high energy needs, especially to } \\
\text { support resistance training program or growth } \\
\text { Convenient and compact source of energy and nutrients for the traveling athlete }\end{array}$ \\
\hline $\begin{array}{l}\text { Liquid meal } \\
\text { supplements }\end{array}$ & $\begin{array}{l}\text { Convenient, portable, and easy-to-consume source of carbohydrate, protein, and micronutrients for } \\
\text { postexercise recovery, including 'recovery' intake before resistance exercise } \\
\text { Low-bulk and practical form of energy and nutrients that can contribute to high energy needs, especially to } \\
\text { support resistance training program or growth }\end{array}$ \\
$\begin{array}{l}\text { Well-tolerated pre-event meal that can be consumed to provide a source of carbohydrate quite close to the } \\
\text { start of a match or workout; seems to be better tolerated than solid food by some athletes with high risk of } \\
\text { gastrointestinal problems } \\
\text { Convenient and compact source of energy and nutrients for the travelling athlete }\end{array}$ \\
$\begin{array}{l}\text { Supplemental source of micronutrients for travelling when food supply is not reliable } \\
\text { Supplemental source of micronutrients during prolonged periods of energy restriction (female athletes) }\end{array}$ \\
\hline $\begin{array}{l}\text { Multivitamin } \\
\text { and mineral } \\
\text { supplement }\end{array}$ & $\begin{array}{l}\text { May provide additional source of sodium for replacement during exercise by cramp-prone players with heavy } \\
\text { sweat and electrolyte losses }\end{array}$ \\
\hline $\begin{array}{l}\text { Electrolyte } \\
\text { supplements }\end{array}$ &
\end{tabular}

Strong potential for ergogenic benefit

Creatine Creatine supplementation increases the creatine phosphate content of muscle and promotes rapid regeneration of adenosine triphosphate by the phosphagen power system. Studies show that creatine loading enhances the performance of exercise involving repeated high-intensity work bouts with short recovery intervals ( $<2$ min recovery). Chronic creatine supplementation may enhance the responses of many fieldbased team sport players to various training protocols - resistance training undertaken by team sport players to enhance muscle mass and strength, interval training undertaken to enhance anaerobic fitness, and matchspecific play. Some studies in the field have shown that acute supplementation enhances the performance of match simulation protocols, or movement patterns within actual field play, and may therefore be seen as a competition aid. More studies of this type are needed across a wider range of field-based team sports. Typical protocols for creatine use: loading dose of 20-30 g in multiple doses (e.g. $4 \times 5 \mathrm{~g}$ ) for 5 days followed by maintenance dose of 2-5 g/day. Uptake appears to be enhanced by consuming creatine with carbohydrate-rich meal or snack. Acute weight gain of about $1 \mathrm{~kg}$ occurs with creatine loading, presumably because of fluid retention

Caffeine May enhance performance of prolonged exercise (e.g. matches) by reducing perception of fatigue. More studies need to be undertaken in team sports to confirm either enhancement of movement patterns or attenuation of decline in skills and concentration over the prolonged period of a match. New studies show that intakes of small to moderate amounts of caffeine (approx. $2 \mathrm{mg} / \mathrm{kg}$ ) may be as effective as the traditional larger doses $(6 \mathrm{mg} / \mathrm{kg})$, especially when taken just prior to the onset of fatigue. Caffeine may be consumed in cola and energy drinks or as an ingredient in some sport products (e.g. some gels). There is conflicting evidence over the efficacy of coffee as a source of caffeine, because it contains other chemicals that might impair performance

Possible potential for ergogenic benefit

Bicarbonate/ The use of bicarbonate or citrate to increase blood-buffering capacity (e.g. $300 \mathrm{mg} / \mathrm{kg}$ body mass bicarbonate citrate or $500 \mathrm{mg} / \mathrm{kg}$ body mass citrate $1-2 \mathrm{~h}$ before the game) might enhance the performance of team sports involving repeated sprints. Field studies are needed with high-level athletes to confirm benefits. Risk of gastrointestinal problems should be noted but appear to be reduced by taking dose with large volumes of fluid (1-2 liters). There is also recent evidence that chronic bicarbonate loading - loading prior to each session of interval training - may enhance training adaptations

$\beta$-Alanine $\quad$ Supplementation with 3-6 g/day $\beta$-alanine has been shown to increase muscle carnosine concentrations and increase intramuscular buffering capacity. Studies are needed in well-trained team players to show if this offers an advantage to training or match play 
ited similar metabolic responses without affecting exercise performance. However, consuming fluid in small volumes reduced the sensation of gut fullness [44].

Nevertheless, limitations exist regarding the ability of team sport athletes to ingest fluid during match play. Indeed, gastric emptying of liquids is slowed during brief intermittent high-intensity exercise compared with rest or steady-state moderate exercise [45], and the intensity of football match play is sufficient to slow gastric emptying [46].

\section{Supplements and Sports Foods for Team Sports}

Like most athletes, team sport athletes are often interested in the potential ergogenic edge that could be gained by means of special supplements. These products are summarized in table 5. Among the proposed ergogenic supplements, creatine is the one that has been investigated the most in relation with team sports, given that its purported ergogenic action (i.e. enhanced recovery of the phosphocreatine power system) matches the activity profile of team sports. Various investigations indicate that both acute and chronic creatine supplementation may contribute to improved training and competition performance in team sports [47-51].

Caffeine ingestion has also been shown to enhance team sport performance by improving speed, power, intermittent sprint ability, jump performance and passing accuracy [52-55]. However, conflicting results are not lacking in the literature [56].

Other dietary supplements with a potential but yet unclear ergogenic effect for team sport performance include induced metabolic alkalosis via bicarbonate ingestion to reduce fatigue during competition $[57,58]$ or to enhance adaptations to training [59]. $\beta$-Alanine supplementation, to increase muscle stores of the intracellular buffer carnosine, may also provide benefits and requires further study using protocols suited to team sports [60]. Colostrum supplementation has a conflicting literature with respect to its effects on recovery and illness [61] but includes one study in which supplementation over 8 weeks improved the sprint performance of hockey players [62].

\section{Practical Nutrition Considerations for the Team Athlete}

Dietary habits of team sport athletes have not been as well studied as those of individual sport athletes. Clark et al. [63] reported on baseline dietary data and performance indices of female football players during rigorous twice-aday preseason training and then during the postcompetitive season. Total energy, carbohydrate, protein, and fat intakes were significantly greater during the preseason. Preseason energy intake met the daily recommended intakes for females with an 'active' lifestyle ( $37 \mathrm{kcal} / \mathrm{kg}$ ). Carbohydrate intake failed to meet recommendations to promote glycogen repletion $(7-10 \mathrm{~g} / \mathrm{kg})$, whereas protein and fat intakes were above minimum recommendations. Pre- and postseason intakes of vitamin E, folate, copper, and magnesium were below $75 \%$ of those recommended.

In a similar investigation, Iglesias-Gutiérrez et al. [64] assessed the food habits and nutritional status of highlevel adolescent football players living in their home environment. Daily energy expenditure and energy intake were $12.5 \mathrm{MJ}$ and $12.6 \mathrm{MJ}$, respectively. Protein (16\% of energy intake; $1.9 \mathrm{~g} / \mathrm{kg}$ of body mass), lipid (38\%), and cholesterol (385 mg) intake were above recommendations, while carbohydrate (45\%) was below. The food intake of these adolescents was based on cereals and derivates; meat, fish, and eggs; milk and dairy products; biscuits and confectionery; and oil, butter and margarine, which provided $78 \%$ of total energy intake, $85 \%$ of proteins, $64 \%$ of carbohydrates, $90 \%$ of lipids, and $47 \%$ of fiber. Although diet provided sufficient iron, $48 \%$ of individuals showed iron deficiency without anemia. Another investigation on football players of various ages [65] also observed that the contribution of carbohydrate to total energy intake was lower than that recommended for athletes. In addition, this contribution decreased with age from $47 \%$ of total energy intake for the 14 -year-olds to $45 \%$ for the adult players. Garrido et al. [66] reported on the adequacy of either a 'buffet-style' diet or a fixed 'menu-style' diet in a group of elite adolescent football players. The set 'menu' provided significantly higher total energy and carbohydrate intakes than the 'buffet', but calories from fat were excessive in both settings. Calcium and vitamin $\mathrm{D}$ were below recommendations in the 'buffet', and fiber, magnesium, folate, vitamin A, and vitamin E intake fell below recommended values in both settings.

All of the above suggest that well-designed nutritional education and interventions are necessary to optimize performance and promote healthy eating habits in team sport players.

\section{Disclosure Statement}

The authors declare no conflicts of interest. 


\section{References}

1 Hawley J, Burke L: Peak Performance: Training and Nutritional Strategies for Sport. St Leonards, Allen and Unwin, 1998.

2 Reilly T, Thomas V: A motion analysis of work-rate in different positional roles in professional football match-play. J Hum Mov Studies 1976;2:87-97.

$\checkmark 3$ Spencer M, Bishop D, Dawson B, Goodman $\mathrm{C}$ : Physiological and metabolic responses of repeated-sprint activities: specific to fieldbased team sports. Sports Med 2005;35: 1025-1044.

4 Rampinini E, Bishop D, Marcora SM, Ferrari Bravo D, Sassi R, Impellizzeri FM: Validity of simple field tests as indicators of matchrelated physical performance in top-level professional soccer players. Int J Sports Med 2007;28:228-235

5 Bangsbo J: The physiology of soccer: with special reference to intense intermittent exercise. Acta Physiol Scand 1994;619:1-155.

6 Ekblom B: Applied physiology of soccer. Sports Med 1986;3:50-60.

$>7$ Matthew D, Delextrat A: Heart rate, blood lactate concentration, and time-motion analysis of female basketball players during competition. J Sports Sci 2009;27:813-821.

$>8$ Reilly T, Borrie A: Physiology applied to field hockey. Sports Med 1992;14:10-26.

$>9$ Stølen T, Chamari K, Castagna C, Wisløff U: Physiology of soccer: an update. Sports Med 2005;35:501-536.

10 Ziv G, Lidor R: Physical attributes, physiological characteristics, on-court performances and nutritional strategies of female and male basketball players. Sports Med 2009;39:547-568

$>11$ Duthie G, Pyne DB, Hooper S: Applied physiology and game analysis of rugby union. Sports Med 2003;33:973-1001.

12 Reilly T: Football; in Reilly T, Secher N, Snell P, Williams C (eds): Physiology of Sports. London, Spon, 1990, pp 371-426.

-13 Tang JE, Moore DR, Kujbida GW, Tarnopolsky MA, Phillips SM: Ingestion of whey hydrolysate, casein, or soy protein isolate: effects on mixed muscle protein synthesis at rest and following resistance exercise in young men. J Appl Physiol 2009;107:987992.

$\checkmark 14$ Moore DR, Robinson MJ, Fry JL, Tang JE, Glover EI, Wilkinson SB, Prior T, Tarnopolsky MA, Phillips SM: Ingested protein dose response of muscle and albumin protein synthesis after resistance exercise in young men. Am J Clin Nutr 2009;89:161-168.

15 Saltin B: Metabolic fundamentals in exercise. Med Sci Sports 1973;5:137-146.

$\checkmark 16$ Krustrup P, Mohr M, Steensberg A, Bencke J, Kjaer M, Bangsbo J: Muscle and blood metabolites during a soccer game: implications for sprint performance. Med Sci Sports Exerc 2006;38:1165-1174.
17 Bangsbo J, Norregaard L, Thorsoe F: The effect of carbohydrate diet on intermittent exercise performance. Int J Sports Med 1992; 13:152-157.

18 Balsom PD, Wood K, Olsson P, Ekblom B: Carbohydrate intake and multiple sprint sports: with special reference to football (soccer). Int J Sports Med 1999;20:48-52.

19 Abt G, Zhou S, Weatherby R: The effect of a high-carbohydrate diet on the skill performance of midfield soccer players after intermittent treadmill exercise. J Sci Med Sport 1998;1:203-212.

20 Akermark C, Jacobs I, Rasmusson M, Karlsson J: Diet and muscle glycogen concentration in relation to physical performance in Swedish elite ice hockey players. Int J Sport Nutr 1996;6:272-284.

21 Zehnder M, Rico-Sanz J, Kuhne G, Boutellier U: Resynthesis of muscle glycogen after soccer specific performance examined by ${ }^{13} \mathrm{C}$-magnetic resonance spectroscopy in elite players. Eur J Appl Physiol 2001;84:443447.

22 Jacobs I, Westlin N, Karlsson J, Rasmusson M, Houghton B: Muscle glycogen and diet in elite soccer players. Eur J Appl Physiol 1982; 48:297-302.

-23 Zehnder M, Muelli M, Buchli R, Kuehne G, Boutellier U: Further glycogen decrease during early recovery after eccentric exercise despite a high carbohydrate intake. Eur J Nutr 2004;43:148-159.

24 Burke L: Field-based team sports; in Burke L (ed): Practical Sports Nutrition. Champaign, Human Kinetics Publishers, 2007, pp 185219.

25 Burke LM: Fuelling strategies to optimise performance - Training high or training low? Scand J Med Sci Sports 2010;20(Suppl 2): 48-58.

26 Baar K, McGee SL: Optimizing training adaptations by manipulating glycogen. Eur J Sport Sci 2008;8:97-106.

27 Hansen AK, Fischer CP, Plomgaard P, Andersen JL, Saltin B, Pedersen BK: Skeletal muscle adaptation: training twice every second day vs training once daily. J Appl Physiol 2005;98:93-99.

$\checkmark 28$ Yeo WK, Paton CD, Garnham AP, Burke LM, Carey AL, Hawley JA: Skeletal muscle adaptation and performance responses to once a day versus twice every second day endurance training regimens. J Appl Physiol 2008;105:1462-1470.

29 Cox GR, Clark SA, Cox AJ, Halson SL, Hargreaves M, Hawley JA, Jeacocke N, Snow RJ, Yeo WK, Burke LM: Daily training with high carbohydrate availability increases exogenous carbohydrate oxidation during endurance cycling. J Appl Physiol 2010;109:126134.
30 Hulston CJ, Venables MC, Mann CH, Martin C, Philp A, Baar K, Jeukendrup AE: Training with low muscle glycogen enhances fat metabolism in well-trained cyclists. Med Sci Sports Exerc 2010;42:2046-2055.

31 Morton JP, Croft L, Bartlett JD, Maclaren DP, Reilly T, Evans L, McArdle A, Drust B: Reduced carbohydrate availability does not modulate training-induced heat shock protein adaptations but does upregulate oxidative enzyme activity in human skeletal muscle. J Appl Physiol 2009;106:1513-1521.

32 Burke LM, Hawley JA: Fluid balance in team sports. Guidelines for optimal practices. Sports Med 1997;24:38-54.

-33 Maughan RJ, Merson SJ, Broad NP, Shirreffs SM: Fluid and electrolyte intake and loss in elite soccer players during training. Int J Sport Nutr Exerc Metab 2004;14:333-346.

34 Shirreffs SM, Aragon-Vargas LF, Chamorro M, Maughan RJ, Serratosa L, Zachwieja JJ: The sweating response of elite professional soccer players to training in the heat. Int J Sports Med 2005;26:90-95.

35 Maughan RJ, Watson P, Evans GH, Broad N, Shirreffs SM: Water balance and salt losses in competitive football. Int J Sport Nutr Exerc Metab 2007; 17:583-594

36 Mohr M, Mujika I, Santisteban J, Randers MB, Bischof R, Solano R, Hewitt A, Zubillaga A, Peltola E, Krustrup P: Examination of fatigue patterns in elite soccer - A multi-experimental approach. Scand J Med Sci Sports 2010;20(Suppl 3):125-132.

37 McGregor SJ, Nicholas CW, Lakomy HKA, Williams C: The influence of intermittent high-intensity shuttle running and fluid ingestion on the performance of a soccer skill. J Sports Sci 1999;17:895-903.

-38 Edwards AM, Noakes TD: Dehydration: cause of fatigue or sign of pacing in elite soccer? Sports Med 2009;39:1-13.

39 Burke L, Cox G: The Complete Guide to Food for Sports Performance, ed 3. Sydney, Allen and Unwin, 2010

40 Nicholas CW, Williams C, Lakomy HK, Phillips G, Nowitz A: Influence of ingesting a carbohydrate-electrolyte solution on endurance capacity during intermittent, highintensity shuttle running. J Sports Sci 1995; 13:283-290.

41 Ali A, Williams C, Nicholas CW, Foskett A: The influence of carbohydrate-electrolyte ingestion on soccer skill performance. Med Sci Sports Exerc 2007;39:1969-1976.

42 Backhouse SH, Ali A, Biddle SJ, Williams C: Carbohydrate ingestion during prolonged high-intensity intermittent exercise: impact on affect and perceived exertion. Scand J Med Sci Sports 2007;17:605-610.

-43 Clarke ND, Drust B, MacLaren DP, Reilly T: Strategies for hydration and energy provision during soccer-specific exercise. Int J Sport Nutr Exerc Metab 2005;15:625-640. 
44 Clarke ND, Drust B, Maclaren DP, Reilly T: Fluid provision and metabolic responses to soccer-specific exercise. Eur J Appl Physiol 2008;104:1069-1077.

$\checkmark 45$ Leiper JB, Broad NP, Maughan RJ: Effect of intermittent high-intensity exercise on gastric emptying in man. Med Sci Sports Exerc 2001;33:1270-1278.

-46 Leiper JB, Prentice AS, Wrightson C, Maughan RJ: Gastric emptying of a carbohydrate-electrolyte drink during a soccer match. Med Sci Sports Exerc 2001;33:19321938.

47 Ahmun RP, Tong RJ, Grimshaw PN: The effects of acute creatine supplementation on multiple sprint cycling and running performance in rugby players. J Strength Cond Res 2005;19:92-97.

48 Cornish SM, Chilibeck PD, Burke DG: The effect of creatine monohydrate supplementation on sprint skating in ice-hockey players. J Sports Med Phys Fitness 2006;46:90-98.

49 Cox G, Mujika I, Tumilty D, Burke L: Acute creatine supplementation and performance during a field test simulating match play in elite female soccer players. Int J Sport Nutr Exerc Metab 2002;12:33-46.

-50 Mujika I, Padilla S, Ibañez J, Izquierdo M, Gorostiaga E: Creatine supplementation and sprint performance in soccer players. Med Sci Sports Exerc 2000;32:518-525.

51 Ostojic SM: Creatine supplementation in young soccer players. Int J Sport Nutr Exerc Metab 2004;14:95-103.
52 Foskett A, Ali A, Gant N: Caffeine enhances cognitive function and skill performance during simulated soccer activity. Int J Sport Nutr Exerc Metab 2009;19:410-423.

53 Roberts SP, Stokes KA, Trewartha G, Doyle J, Hogben P, Thompson D: Effects of carbohydrate and caffeine ingestion on performance during a rugby union simulation protocol. J Sports Sci 2010;28:833-842.

54 Schneiker KT, Bishop D, Dawson B, Hackett LP: Effects of caffeine on prolonged intermittent-sprint ability in team-sport athletes. Med Sci Sports Exerc 2006;38:578-585.

55 Stuart GR, Hopkins WG, Cook C, Cairns SP: Multiple effects of caffeine on simulated high-intensity team-sport performance. Med Sci Sports Exerc 2005;37:1998-2005.

56 Paton CD, Hopkins WG, Vollebregt L: Little effect of caffeine ingestion on repeated sprints in team-sport athletes. Med Sci Sports Exerc 2001;33:822-825.

57 Bishop D, Claudius B: Effects of induced metabolic alkalosis on prolonged intermittent-sprint performance. Med Sci Sports Exerc 2005;37:759-767.

58 Tan F, Polglaze T, Cox G, Dawson B, Mujika I, Clark S: Effects of induced alkalosis on simulated match performance in elite female water polo players. Int J Sport Nutr Exerc Metab 2010;20:198-205.

-59 Edge J, Bishop D, Goodman C: Effects of chronic $\mathrm{NaHCO}_{3}$ ingestion during interval training on changes to muscle buffer capacity, metabolism, and short-term endurance performance. J Appl Physiol 2006;101:918925.
60 Derave W, Everaert I, Beeckman S, Baguet A: Muscle carnosine metabolism and beta-alanine supplementation in relation to exercise and training. Sports Med 2010;40:247-263.

61 Shing CM, Hunter DC, Stevenson LM: Bovine colostrum supplementation and exercise performance: potential mechanisms. Sports Med 2009;39:1033-1054.

-62 Hofman Z, Smeets R, Verlaan G, Lugt R, Verstappen PA: The effect of bovine colostrum supplementation on exercise performance in elite field hockey players. Int J Sport Nutr Exerc Metab 2002;12:461-469.

63 Clark M, Reed DB, Crouse SF, Armstrong RB: Pre- and post-season dietary intake, body composition, and performance indices of NCAA division I female soccer players. Int J Sport Nutr Exerc Metab 2003;13:303-319.

64 Iglesias-Gutiérrez E, García-Rovés PM, Rodríguez C, Braga S, García-Zapico P, Patterson AM: Food habits and nutritional status assessment of adolescent soccer players. A necessary and accurate approach. Can J Appl Physiol 2005;30:18-32.

65 Ruiz F, Irazusta A, Gil S, Irazusta J, Casis L, Gil J: Nutritional intake in soccer players of different ages. J Sports Sci 2005;23:235-242.

66 Garrido G, Webster AL, Chamorro M: Nutritional adequacy of different menu settings in elite Spanish adolescent soccer players. Int J Sport Nutr Exerc Metab 2007;17:421-432. 